\title{
THE SCIENTIFIC SURGEON
}

\section{Presidential Address: British Orthopaedic Association, Manchester, April 14, 1961}

\section{H. J. Seddon, London, England}

In the development of orthopaedics in this country there is much of which we may be proud. We have made many contributions to our craft, and have pioneered the development of regional hospitals and their peripheral clinics. There is still more to be done-ubiquitous accidents pose new problems of organisation and treatment-indeed, more than enough to occupy all our efforts and skill. The result is that there is all too little time to spare for studying the phenomena of injury and disease, or even to examine current methods of treatment with calm detachment. Good practice is to some extent the enemy of science. This is not peculiar to orthopaedics; it obtains in every branch of medicine and in many other kinds of human endeavour. So I am going to say something about research in relation to orthopaedics.

Discourses on research or on the art and science of medicine have been given with dismal frequency. Two features appear fairly regularly. The orator often betrays an uneasy consciousness of the apparent conflict between the scientific advancement of medicine and its practice. In a series of addresses, remarkable alike for their erudition and for the beauty of their language, Walshe $(1948,1950,1956)$ set out to prove that there is, after all, no conflict. I wish I could be convinced. Another speaker, Arnott (1955), denounced the empiricism of medicine root and branch and thought the whole business should be cleaned up. The other and more interesting feature is the light these addresses often throw on the mind of the orator. They tend to be an apologia pro vita sua. I am aware of this risk in speaking to you today.

Let me say straight away that the conflict between science and practice is there; we must face it. We are now in the realm of ideas. But different ways of thinking come from different kinds of men, and there are many such in medicine. Let me describe four types to you by the cruel but evocative art of caricature, a sort of Hogarth portrait gallery.

1. The Scientist. He is often pictured as bearded, wearing a leather-bound tweed jacket, a regular reader of the New Statesman, a violinist, a connoisseur of wines. He may seem to lack humanity; one man with whom I once worked habitually referred to the patient as " the preparation." His Olympus is the Royal Society; his apotheosis the Nobel Prize.

2. The Consultant. Bernard Shaw's Cutler Walpole. He exudes charm, is impeccably dressed, and his waistcoat is double-breasted. The absence of any original idea beneath his brow has kept it unfurrowed. An elegant way of life and a certain place in society are regarded as indispensable. His Valhalla is the Council of the College of Surgeons; he even dreams of becoming President, ruler of that great empire in which the concrete never sets. He does not understand that without certain higher qualities he can never get there.

3. The Missionary. A very different type. He practises medicine because somewhere deep inside him is a real devotion to his fellow men. He may come from a great family of doctors. $\mathrm{He}$ is most conscientious though he may do the wrong thing, for the reason that he gives so generously of his time to good causes that he can never quite get round to becoming competent. 4. The Administrator. The organiser, the committee man, the negotiator. A splendid speaker, most useful in his way, indeed indispensable. What he really loves is power, what he covets is public recognition.

These are crude, harsh sketches, though occasionally one finds these people in real life. Most of us are a mixture and this is what makes us such fascinating creatures; but one 
characteristic often predominates. Today I am concerned only with the scientist and the capable practitioner because they represent the Science and the Art of Medicine. We must not fight shy of the conflict between them; it is inevitable and it can be healthy. Freedom to differ is essential for the development of the mind. But with it-and this is true of nations, social and professional groups, and of individuals-there must be tolerance. What counts is the breadth of a man's mind and sympathies.

The full-time scientist leads an exacting life, but, if he is a wise man, it is designedly simple. The pursuit of learning has long been associated with the cloister. This is illustrated most graphically by the colleges of our ancient universities where, even today, a man may retire into his cell and devote himself to original work. The clinician, by contrast, lives in the bustle of the market place. The world presses round him; his patients see to that. Yet there are temptations common to the don and to the hospital consultant. The allurements of administration can break through the stoutest college gates and many a promising young scholar has become a university busybody. If the clinician is to make use of the unique opportunities for learning which the practice of medicine affords, he must create his own retreat, and limit his outside commitments and distractions. His way of life must be simple, otherwise he will have no time to think.

In medical practice some environments are more conducive than others to research; some carry special obligations.

1. At the frontiers of medicine, as we see them in young territories overseas, the pressure of routine work is overwhelming; a man has to confine himself to what he can do most profitably with limited resources and perhaps no skilled assistance. If he finds that his natural curiosity is leading him into some sort of investigation he must seek a change of environment, and fortunately this is possible. Men with ideas are at a premium.

2. In regional hospitals the orthopaedic surgeon may have to work alone or with one other colleague. These men have to be good all-rounders and to be shrewd in the selection of the methods they employ for the conditions that demand most of their attention. If they are wise they do not dabble with rarities but decant them to the nearest big centre. If the grind of work does not exhaust them they may make excellent contributions in the clinical field. One of the most striking examples was Brittain of Norwich. These men are invaluable because they see orthopaedics as a whole.

3. The undergraduate teaching hospital. This is part of a seat of higher education and by definition research is one of its activities. A man can be a good teacher, an excellent practitioner and do no research. He will be remembered by his pupils, perhaps revered by them, but he will have failed to some extent in his destiny if he has not brought those in his charge to the frontiers of the unknown, and encouraged distrust in cant and dogma. They will see no promised land beckoning them. The surgeon on the staff of a teaching hospital must have at least a sympathy with and some understanding of research, even though his own gifts may not lead him in that direction.

4. Lastly, we come to the special hospital of which this country has a considerable number. They were founded to make provision for patients for whom the general hospitals did not adequately cater, and for the advancement of knowledge in a particular field. If the special hospital with its peculiar advantages fails to promote research, to advance knowledge, it neglects one of its purposes. Some have failed and we may find that the penalty for this is dissolution.

So much for the background. Now, may I address myself more particularly to younger members of this Association who still have their professional life before them? To you is committed a part of the future of medicine. In this audience there are a number of men who although not passionately devoted to research (if they were they would be seeking their careers elsewhere) are sufficiently endowed with curiosity and the capacity to think and work

VOL. 43 B, NO. 4, NOVEMBER 1961 
scientifically to fit them to advance medicine. Here are a few simple observations which will repel or attract you, but to which you cannot be indifferent.

1) Endurance. Any quest for knowledge calls for hard work. Inspiration without it is like faith without works-dead, being alone.

The heights by great men reached and kept

Were not attained by sudden flight, But they, while their companions slept, Were toiling upwards in the night.

Longfellow, The Ladder of St Augustine

This, you may think, savours too much of Samuel Smiles. Perhaps so, but the Victorian virtues are not to be despised. 2) A simple way of life. My favourite example in British surgery is Lord Lister. If you read Godlee's biography carefully you may come to the conclusion that has been forced on me-I put it to you very humbly - that he was not a supremely clever man. It was simplicity and childlike honesty that marked his thoughts and work. He had to earn his living in consulting practice though he was never a brilliant surgeon. Yet, from his earliest days he had an astounding grasp of what mattered; and with it went a dogged determination to pursue those experiments and practices that placed the whole world in his debt. And a glorious harmony marked his long and fruitful life. I know men today of like character though the times do not invest them with Lister's heroic lineaments. 3) No time like the present. Research is a young man's game. Granit, the great Swedish physiologist, once told me that a man's best work is done before the age of forty-five. Apart from the springs of originality running dry, the burden becomes too heavy as the years pass. For us there is a difficulty here. In clinical medicine a certain amount of experience is necessary before the investigator can get an eye for a problem. Yet the discerning young man will often spot it and we must provide means for him to work on it while the problem is still fresh in his mind. Don't wait: time is not on your side. 4) Undue modesty. Experience counts for so much in clinical medicine that the tyro may feel seriously inhibited by his lack of it. I cannot do better here than quote that great Spaniard, Ramón y Cajal (1951): "I consider among the most doleful preoccupations of intellectual youth is undue admiration for the work of great minds ... This excessive devotion to genius has its roots in a feeling that is a compound of justice and modesty much too commendable to be censured. Nevertheless, if it takes overweening possession of the mind of the novice, it destroys all initiative and totally incapacitates him for original investigation. Defect for defect, arrogance is preferable to diffidence; boldness measures its forces and conquers or is conquered, but excessive modesty flees from the battle and is condemned to shameful inactivity." Or more tersely, more sternly, St Paul to Timothy, "Neglect not the gift that is in thee. Let no man despise thy youth." 5) Concentration. When you have got your teeth into something, keep them there. You will have noticed how great scientists-like Adrian and Dale; in surgery, Penfield-have followed much the same type of work throughout a long and fruitful lifetime. The lists of papers I see appended to applications for senior appointments are sometimes depressing, a pot-pourri of superficial contributions on far too many subjects. When you have found an interesting line of work stick to it; don't be distracted by every other seductive idea that comes along. 6) The approach to a topic. There are distinct stages in the handling of a subject. There is the first flush of enthusiasm, when interest is aroused. Then you begin to wade through the literature and disillusionment creeps in. It seems that others have done everything. Don't be discouraged. As you ponder you will become aware of the gaps in our knowledge or of ideas long accepted as gospel but palpably unsound, and that must be challenged. Write out what you plan to do, then set to work. After five years or so you may find you are stuck; 
it appears there is nothing more to be done. Turn your mind to something else for a while. Later you may return to your first love, and the chances are that you will once more find something new which you take up with an interest sweetened by long association. Before you know where you are it is only ten years before you are due to retire, and the shortness of life for a man who seeks knowledge will be brought home to you with startling urgency. 7) The sacrifice of all-round competence. There are exceptional men who excel both scientifically and in comprehensive practice in their field of surgery. But most of us with an interest in the science of surgery are compelled to limit our repertoire so far as operative work is concerned, simply because technical skill is largely a matter of practice and practice takes time. This limitation applies only to the more complex forms of treatment. It must not be tolerated in diagnosis or in our grasp of medicine as a whole. It is noticeable that scientists intensely devoted to one line of investigation often display an astonishing breadth of interests. This is a mark of the cultivated mind. But in the sort of work that you and I do it means that if we are to find time for research we must be prepared to hand over patients with certain conditions to colleagues particularly skilled in the treatment of them. This is not specialisation within a speciality: it is plain commonsense. It enables a group of surgeons, perhaps covering a wide area, to help each other forward. This is one kind of team work.

As surgeons we have certain advantages over other clinicians, for we are able to look inside the human body. The operation theatre is the greatest of all laboratories in medicine and it is ours. The trouble is that we too often approach it as if it were the stage.

a) An operation may enable us to observe phenomena or collect material which have no direct connection with the operation itself. Kellgren in this city made observations on the sensibility of articular structures during the course of operations on the knee under local anaesthesia.

b) The operation may yield information about the nature of a disorder. This is how Mandl cleared up the mystery of hyperparathyroidism: this is how we found the causes of median paralysis at the level of the carpal tunnel and of paralysis of the deep branch of the ulnar nerve.

c) The operation may be part of a planned trial to determine whether one method is better than another; here there must be the most searching documentation of pre- and post-operative conditions. But as I shall explain in a moment, this sort of thing is all too rare.

d) The operation may itself be an experiment, the aim being to achieve a result previously unattainable, or to obtain a good result more surely, more safely, more simply than before. For this the most intensive preparation is necessary, perhaps involving animal experiment, as in the recent spectacular work on the heart. Inadequate preliminary work or publication of a new method before sufficient time has elapsed for the disclosure of possible shortcomings can be disastrous. Need I do more than remind you of some of the recent work on the reconstruction of the hip joint?

Now supposing you have hit on something that looks really good; it may be a new operation, or a non-operative method of treatment. You identify yourself with it, you become a partisan, an advocate. That is fair enough-but only at first. There is quite a chance that an equally competent surgeon a hundred miles away will claim that he can get as good or even better results by a quite different method. What happens? The secretary of a surgical society arranges a "boxing match" between you and your rival, and we who listen to you both are supposed to make a decision on points, a knock-out being too much to hope for. But your supporters, and the other fellow's, each go away muttering: "The two series aren't comparable. I think Tweedledum (or Tweedledee) is right." And there the matter rests, a colossal waste of time, but good fun.

Physicians do these things better, I suppose because they do not invent the drugs they use and because no great technical prowess is required in getting a patient to swallow a pill. 
They really get somewhere with their clinical trials. Perhaps we may rise to these heights one day.

And now a few words about conditions today. There is this antinomy between practice and research, inherent in clinical medicine because practice is often unpredictable and sometimes urgent, whereas research requires freedom from interruption. Yet many great men and some not so great have overcome it; it should not be beyond us.

The difficulties can be aggravated by hostility between those interested in practice and those with a taste for clinical investigation. There are faults on both sides. The professorial units, for example, sometimes remain aloof in our medical schools. I recall a remark of one of our greatest professors of medicine who deplored the "insufferable intellectual arrogance" of some heads of academic clinical departments. On the other side, I recall an occasion when an applicant for a senior appointment at one of our greatest postgraduate teaching hospitals was rejected on the advice of its senior surgeon because, we are told, a man who like this candidate had done outstanding research work could not possibly be much good as a surgeon. I knew the man intimately, but my protest was unavailing. As it turned out all was well for he soon obtained an even better appointment in a more enlightened place.

I have known other good junior men, doing excellent research, who were unhappy because they feared that unless they devoted all their energies to clinical practice they would fall behind in the stern competition for senior appointments. Yet not one of them suffered a setback.

The moment our good young investigator attains consultant status his new-found freedom is assailed from two quarters. The temptation to "fill up his sessions" is understandably strong and if he does his work conscientiously-as he will, being a good man-he will hardly have time or the freshness of mind required for continuing his research. And then there are the claims of private work.

I am certain that private consulting practice is the greatest of all hindrances to research. The solution propounded by the Goodenough Committee (following on the Haldane Committee) and increasingly put into effect during the last fifteen years was the establishment of full-time clinical units in all teaching hospitals. There is not the slightest doubt that these units have given scientific medicine a great boost. But this is not the whole answer. The professorial system has difficulties of its own, which I will not trouble you with now; and it is harvesting only a part of the great field. Furthermore, I suspect that a little consulting practice has a healthy disciplinary effect on the clinician. The difficulty is keeping it within strict limits. It can be done by the gentle art of saying No. This will have to be learnt and applied rigorously by a man who is not content to be the plaything of circumstance, and it is a cardinal prerequisite if time is to be found for research.

It was hoped that the Clinical Research Board would foster enterprise wherever it was found. It was to be a handmaiden of the National Health Service, but it has, in fact, developed as a committee of the Medical Research Council, and has not yet acquired a mind of its own. Nevertheless, this Board is manned entirely by clinicians, and has funds at its disposal for the support of the enterprising part-timer. When I was a member the Board was still skating gingerly round the nub of the problem, how to make provision for the part-timer able and keen to engage in research, so that a certain part of his week be set apart for this purpose. The difficulty was to find a way of decanting him back painlessly and renewing his hospital sessions if he or the Research Board came to the conclusion that his fruitfulness in research was petering out. I think this problem will be solved before long. Money for research expenses is, fortunately, not hard to come by, if a project is a sensible one.

The burden of my song is this. We are primarily practitioners and our work is peculiarly satisfying. But the opportunities that we alone enjoy call for the exercise of scientific method; this requires discipline, much thought and a certain amount of time. 
For a number of years past I have been a privileged person; I have not had to wrestle with the mass of routine work that burdens many of you, my friends. Yet I trust I do not underestimate the difficulties of escaping from the servitude of practice. Many of you have shown that it can be done. In this Association there are men who by the careful ordering of their lives and undoubted sacrifice are adding to knowledge, amateurs in the strict and best sense of the word, doing the job for the love of the thing. Their example is worth more than all my precepts.

\section{REFERENCES}

Arnott, W. W. (1955): The Climate of Discovery. Lancet, ii, 783.

Ramón y CAJal, S. (1951): Precepts and Counsels on Scientific Investigation; Stimulants of the Spirit. Translated by J. M. Sanchez-Percz. Edited and annotated by Cyril B. Courville. California: Pacific Press Publishing Association, Mountain View.

Walshe, F. M. R. (1948): Harveian Oration. The Structure of Medicine and its Place among the Sciences. Edinburgh: E. \& S. Livingstone.

WALSHE, F. M. R. (1950): Linacre Lecture. Humanism, History, and Natural Science in Medicine. British Medical Journal, ii, 379.

Walshe, Sir F. (1956): Medicine in the Framework of the University. British Medical Journal, i, 1,441. 